\title{
Black Swan, Grey Swan? Pandemic Scenarios and African Peace and Security Futures
}

\author{
Ulf Engel
}

\section{Introduction}

In the world of states, international organizations and national governments are dealing with futures every day. These futures are constructed in many ways and in different social arenas (Appadurai 2013; Goldstone and Obarrio 2017). Obviously, in politics they can become fairly crucial for everyone's life. Policy planning has to prepare for tomorrows that are usually unknown, or at least difficult for contemporaries to grasp fully, depending on the time horizon. How exactly this is done may differ from case to case. Policy actors routinely make use of various future-constructing techniques - from 'outlooks' to 'perspectives', from 'trends' to 'prognosis', and from 'scenarios' to 'forecasts'. These techniques are based on different, distinct methodologies, which have in common that they aim to look at concrete events and incidents, but also relevant developments beyond today's seemingly apparent certainties (Tetlock and Gardner 2016).

In this short contribution, I am interested in very general terms in how African futures in the politico-security realm have, if at all, narrated the threat of epidemics and pandemics. To what extent was the outbreak of something like the coronavirus part of relevant African future scenarios and, thus, could have come onto the radar of relevant decision-makers? More concretely, I will look at how epidemics such as Ebola and pandemics like the acute respiratory syndrome COVID-19 have been identified as threats to peace and security. Off the cuff, most people would agree with the statement that COVID-19 is, what in this trade is called, a black swan - something that is highly improbable and therefore not predictable or foreseeable at all (Taleb 2007). In the area of politics, prominent and often cited examples of black swans are the Jom Kippur war of 1973, the collapse of the Soviet Union in 1990/1, the 1994 genocide in Rwanda, the attacks of $9 / 11$ in 2001, or the uprisings in North Africa and the Middle East in 2011. Interestingly, in hindsight most of these events actually turned out to be grey swans - that is events for which early warning information was in fact available within the respective system, often the intelligence community or specific early warning systems (see Engel 2019), but for various reasons was not recognized, acknowledged or followed-up (see Davis 2016; Jervis 20o9).

(C) ULF ENGEL, 2022 | DOI:10.1163/9789004471641_015

This is an open access chapter distributed under the terms of the CC BY-NC 4.0 License. 
In the following I will, first, briefly recall how in the mid-2o1os the African Union framed epidemics as a so-called 'non-traditional' peace and security concern. Second, I will scrutinize three prominent politico-security scenarios that have been developed in recent years on African futures: how are they discussing the relevance of epidemics and pandemics? So, the question discussed here is not whether the outbreak of CoviD-19 was predictable, but to what extend it could have been on the radar of relevant decision-makers. This is followed by brief conclusions.

\section{The African Union and the Making of 'Non-Traditional' Peace} and Security Threats: Epidemics and Pandemics

The Ebola epidemic broke out the first time in 1976 near a river called Ebola (the 'black river') in the northern part of the Democratic Republic of Congo (DRC). Since, regular outbreaks of the disease have been recorded. Following renewed onsets of Ebola in 2014 in West Africa (Guinea, Liberia and Sierra Leone) as well as in the DRC, Ebola got onto the radar of the African Union (AU). The AU Assembly of Heads of State and Government made reference to the epidemic for the first time in 2012 (AU Assembly 2012), following a smaller number of incidents in the DRC and Uganda. In those days it was treated as a public health issue that called for regional coordination of public health systems. But this discourse shifted with the new outbreaks of Ebola in 2014 in West Africa, partly because post-conflict countries with little societal resilience were affected. The debate was taken to the AU Peace and Security Council (PSC), the highest decision-making body between biannual summits. Ebola was discussed on 19 August 2014 (45oth PSC meeting), 29 October 2014 (464th meeting), 28 November 2014 (471st meeting) and 19 December 2014 (478th meeting). And, while the AU Assembly continued to coordinate the disease prevention and mitigation efforts of member states (AU Assembly 2015a), Ebola was also linked to post-conflict reconstruction and development policies in affected countries (AU Assembly 2015b), especially those that have come out of civil wars, like Liberia (1989-97, 1999-2003) and Sierra Leone (1991-2002). This firmly established epidemics as a 'non-traditional' security threat on the agenda of the African Union, and warranted the attention of the continental body as well as the regional economic communities and AU member states alongside El Niño and illicit financial flows. This new awareness also led to the establishment of the Africa Centres for Disease Control and Prevention (Africa CDC) to equip the Union with a monitoring and coordination mechanism (see Engel 2020). Around 2014/15, epidemics also become a data monitoring 
category for the AU Continental Early Warning System (CEWS), which is advising the chairperson of the AU Commission and the PSC on courses of action to prevent or mitigate violent conflict. ${ }^{1}$

"The Future ... is no Longer Quite What it Used to be"2 - African Futures Scenarios

On the eve of 2020, academic and journalistic layperson forecasts for 'Africa in the year 2020' did not capture pandemics as an important upcoming issue. Analysis was limited to the 'known knowns', such as upcoming elections or ongoing violent conflict (see, for instance, Africa Report 2019; Lakemann and Lierl 2020; Malley 2019). As usual, little attention was paid to the known unknowns', or even the 'unknown unknowns'. But how about more systematic and professional efforts at scenario-building? In the following, and in the tradition of private sector and intelligence contributions to this field, scenarios are treated as a tool for planning and decision-making. They

represent a distinct, plausible picture of a segment of the future. Because it is impossible to know the future precisely, the solution is to create several scenarios. These scenarios are, essentially, specially constructed stories about the future, each one modelling a distinct, plausible outcome. CLARK 2004: 173

In the past decade, three scenarios for African futures stand out - the African Futures 2050 Report published by the Institute for Security Studies (ISs) (Cilliers et al. 2011); the African Futures: Horizon 2025 of the European Union Institute for Security Studies (EUISS) (Arnould and Strazzari 2017); and the US National Intelligence Council's (NIC) Global Trends Report: Sub-Saharan Africa (NIC 2017). Obviously, the three scenarios have been produced at different moments in time (2011 and 2017 respectively), are addressing different temporal horizons (from 2025 to 2050), and target different audiences.

The African Futures 2050 Report is the product of a partnership between the Pretoria-based Iss and the Frederick S. Pardee Center for International Futures at the University of Denver, Colorado. It is a forecasting tool, based on an 'international futures' model. The target audience includes the NEPAD Planning and

1 Personal observations at the AU Peace and Security Department, Addis Ababa, 24 September 2014, 16 January 2015 and 18 March 2015.

2 Valéry (1948: 135). The French poet and philosopher Paul Valéry (1871-1945) coined a version of the phrase in French in 1937 in an essay titled "Notre destin et les lettres". 
Coordination Agency, the African Development Bank, the UN Economic Commission for Africa, and the African Union, among others. The report was published in 2011, that is before the crucial Ebola outbreak in West Africa. It looks at a time horizon of forty years. African Futures 2050 discusses various peace and security dynamics. Increasing urbanization and the governance of complex urban spaces, climate change, drugs-related violence, (politized) religion, military capacities and the resilience of societies are identified as the main drivers or game changers (Cilliers et al. 2011: 76-9). The Ebola epidemic is not mentioned in the scenario, though attention is paid to HIV/AIDs (Cilliers et al. 2011: 11, 17, 18, 25, 70).

African Futures: Horizon 2025 is a forecasting report published in 2017 by the Paris-based EU Institute for Security Studies, the EU agency for analysing foreign, security and defence policy issues. Previous studies have been conducted on the Arab world (2015), Russia (2016) and China (2017). The report identifies a number of 'systemic' and 'macrosocial drivers' for African futures. The latter include 'epidemics', with the other drivers in this category being demographics, gender attitudes, education and corruption. However, the report remains fairly vague and unspecific and Ebola is not mentioned as such. As Arnould and Strazzari (2017:9) put it:

Lastly, while advances have been made in tackling certain serious diseases such as HIV/AIDS and reducing infant mortality, periodic public health crises and epidemics will continue to pose significant challenges in Africa over the longer term, and may even increase under the effect of climate change. These not only carry high human costs but also economic and political costs that will determine whether some of the identified socio-political and economic transformations will produce positive or rather negative effects.

Finally, every four years the US National Intelligence Council (Washington DC) produces a five-year forecast and strategic assessments based on open sources. Within the set of the three scenario reports analysed here, the NIC 2017 forecast has a very short time horizon (2017-21). Unlike the Iss and EUISs, the methodology is descriptive and explorative, rather than strictly scenario-based. The overall forecast states that "in the next five years, sub-Saharan Africa will become more populous, youthful, urban, mobile, educated, and networked" (NIC 2017:117). The main drivers of the scenario are "mass mobilization, urbanization, and religious affiliation". And the violence forecast highlights that "complex security problems will mount, ethnic tension escalate, and religious extremism, particularly radical Islam and fundamentalist Christianity, will spread even further" (NIC 2017: 117). The report does not discuss epidemics or 
pandemics in particular, though it briefly mentions challenges that "transcend national borders and individual states' capacities and require coordinated multinational action" (NIC 2017: 118). However, the report clearly emphasizes that previous actions on HIV/AIDS and Ebola "spotlight the potential for further health gains through partnerships between African states and the international community" (NIC 2017: 121).

The question addressed in this vignette was to what extent the outbreak of COVID-19 could have been on the radar of relevant decision-makers, and what kind of African futures have been developed in this respect. It seems that for African decision-makers, CoviD-19 was more of a black than a grey swan. On the one hand, and after the Ebola crisis in West Africa (2014-16), the levels of preparedness of the African Union had risen through the launching of the Africa CDC in 2017. This was supported by ongoing debates in the PSC on the security threat that epidemics and pandemics can potentially pose. This seems to indicate that there was general, yet not case-specific awareness. On the other hand, no one 'forecasted' or 'predicted' that something like the coronavirus could make its landfall on the continent. However, at least some institutions were in place to monitor the outbreak and, so some extend, coordinate policy responses (Engel 2020). This differs from the few prominent scenarios published on African futures over the last decade (ISS, EUISS, NIC). They only superficially discuss the likelihood of a deadly pandemic of this kind, which is in stark contrast to the other scenarios already published elsewhere in 2013 (see D BT 2013). ${ }^{3}$ So, with regard to the latter, at least from a scenario-building perspective, COVID-19 is indeed a grey swan: there was early warning information available - a plausible future was described. Yet, decisions-makers did not take it up for policy planning purposes. This happens rather often with scenarios. This is partly explained by the different cognitive mindsets and operational cultures in which scenario-builders and decisions-makers are living

3 In 2013, the German government tabled a report to parliament on its risk assessment regarding the civil protection of the German population (drafted by the Berlin-based Robert Koch Institute, the government's central institution for biomedicine). Among others, the scenario describes how a hypothetical modification of the SARS virus, in this case originating from Asia, is spreading across the globe (DBT 2013: 5). Needless to add, that in this case a good scenario did not trigger the necessary policy responses with respect to increasing the preparedness of the public health system. Of course, one can only speculate about the reasons for this. 
(Brozus 2018: 20; see also Davis 2016; Jervis 2009). Both perspectives looked at in this text - policy considerations and think tank-driven scenario-building illustrate the practical relevance of producing African futures, but also underline the need to produce methodologically sound approaches. Finally, this is also a timely reminder of the challenges involved in linking this kind of early warning information in systematic ways to policy planning and decision-making processes.

\section{Acknowledgement}

Work on this text was supported by German Research Council (DFG) grant SF B 1199 "Processes of Spatialization under the Global Condition".

\section{References}

Africa Report. 2019. "Top African elections to watch and predictions for 2020". 23 December. https://www.theafricareport.com/21584/top-african-elections-to-watchand-predictions-for-2020/ [2 January 2021].

Appadurai, A. 2013. The future as a cultural fact: Essays on the global condition. London: Verso.

Arnould, V. and F. Strazzari (Eds). 2017. African futures: Horizon 2025 (EUISs report 37). Paris: European Union Institute for Security Studies.

AU Assembly. 2012. "Decision on African integration". Adopted at the 18th ordinary session of the AU Assembly held in Addis Ababa, Ethiopia, 29-30 January. Assembly/ AU/Dec. 392 (XVIII).

AU Assembly. 2015a. "Decision on Ebola virus disease (EVD) outbreak". Adopted at the 24th ordinary session of the AU Assembly held in Addis Ababa, Ethiopia, 30-31 January. Assembly/AU/Dec. 553 (XXIV).

AU Assembly. 2015b. "Decision on the report of the Peace and Security Council on its activities and the state of peace and security in Africa." Adopted at the 24th ordinary session of the AU Assembly held in Addis Ababa, Ethiopia, 30-31 January. Assembly/Au/Dec. 559 (XxIV).

Brozus, L. 2018. "Fahren auf Sicht. Effektive Früherkennung in der politischen Praxis." Berlin: Stiftung Wissenschaft und Politik.

Cilliers, J., B. Hughes and J. Moyer. 2011. African futures 2050 report. Pretoria/Denver: Institute for Security Studies/Frederick S. Pardee Center for International Futures.

Clark, R. 2004. Intelligence analysis: A target centric approach. Washington, DC: CQ Press. 
Davis, J. 2016. "Why bad things happen to good analysts", Studies in Intelligence, 6o, 3: $14-24$.

DB T (Deutscher Bundestag). 2013. "Unterrichtung durch die Bundesregierung. Bericht zur Risikoanalyse im Bevölkerungsschutz 2012.” Berlin: Deutscher Bundestag.

Engel, U. 2019. "Early warning and conflict prevention". In The Routledge Handbook on Transregional Studies, edited by M. Middell, 573-581. London: Routledge.

Engel, U. 2020. Public Health Policies beyond the State: A Socio-spatial Analysis of Early Responses to Covid-19 in Africa, 2020. ReCentGlobe working paper series 41. Leipzig University.

Goldstone, B. and J. Obarrio (Eds). 2017. African futures. Essays on crisis, emergence, and possibility. Chicago, IL: Chicago University Press.

Jervis, R. 2009. "Black swans in politics”, Critical Review, 21, 4: 475-489.

Lakemann, T. and M. Lierl. 2020. "Zehn entscheidende Entwicklungen in Afrika im Jahr 2020." GIGA Focus Afrika, 1. https://pure.giga-hamburg.de/ws/files/21509199/ gf_afrika_20o1.pdf.

Malley, R. 2019. "10 conflicts to watch in 2020", Mail \& Guardian (Johannesburg), 28 December. https://mg.co.za/article/2O19-12-28-10-conflicts-to-monitor-in-2O2O [2 January 2021].

NIC. 2017. Global trends: Paradox of progress. Washington, DC: National Intelligence Council. https://www.hsdl.org/?view\&did=7979o8 [2 January 2021].

Taleb, N. N. 2007. Black swan. The impact of the highly improbable. London: Penguin.

Tetlock, P. E. and D. Gardner. 2016. Superforecasting. The art and science of prediction. London: Random House.

Valéry, P. 1948. Reflections on the world today. New York: Pantheon. (Translated from: Valéry, P. 1937. "Notre destin et les lettres". Paris: Université des Annales publié dans Conferencia.) 